\title{
Sources of epigraphs
}

\section{In order of appearance}

Thomas de Quincey (1897). 'Joan of Arc'. The Collected Writings V. ed. David Masson.

London: A. \& C. Black, p. 406.

Sigmund Freud (1926). Inhibitions, Symptoms and Anxiety. Standard Edition XXI, London:

The Hogarth Press, p. 125.

Sylvia Plath (1981). 'Edge'. The Collected Poems. New York: Harper \& Row, p. 272.

Jacques Derrida (1979). Spurs: Nietzsche's Styles. Chicago: University of Chicago Press, p. 89.

Walter Benjamin (1974). Ursprung des deutschen Trauerspiels. Gesammelte Schriften 1.1. Frankfurt am Main: Suhrkamp, p. 284.

Sigmund Freud (1930). Civilization and its Discontents. Standard Edition XX. London: The Hogarth Press, p. 90.

Aristotle (1954). Poetics. New York: Modern Library, p. 227.

J.-P. Vernant (1989). 'Dim Body, Dazzling Body'. Fragments for a History of the Human Body. Part One. ed. Michel Feher. New York: Zone, p. 21.

Michel Serres (1987). Statues. Le second livre des fondations. Paris: François Bourin, p. 43.

Nancy Huston (1990). Journal de la création. Paris: Seuil, p. 27.

Michel Deguy (1969). Figurations. Paris: Gallimard, p. 122.

Christina Rossetti (1974). 'In an Artist's Studio'. The World Split Open. Four Centuries of Women Poets in England and America, 1552-1950 ed. Louise Bernikow. New York: Vintage, p. 125.

Richard Huntington and Peter Metcalf (1979). Celebrations of Death. The Anthropology of Mortuary Ritual. Cambridge: Cambridge University Press, p. 2.

Jacques Lacan (1978). The Four Fundamental Concepts of Psychoanalysis. New York: Norton, p. 263.

Simone de Beauvoir (1974). The Second Sex. New York: Vintage, p. 223.

Jacques Lacan (1985). 'God and the Jouissance of The Woman. A Love Letter'. Feminine Sexuality, ed. Juliet Mitchell and Jacqueline Rose. New York: Norton, p. 145.

Walter Benjamin (1974). Ursprung des deutschen Trauerspiels I.1. Frankfurt am Main: Fischer, p. 354.

Bonaventura (1984). 'Der Traum der Liebe'. Nachtwachen. Stuttgart: Reclam, p. 88.

Paul Ricoeur (1970). Freud e Philosophy. An Essay on Interpretation. New Haven, Yale University Press, p. 293. 
Kathy Acker (1986). Don Quixote. London: Paladin, p. 33.

Barbara Johnson (1980). The Critical Difference. Baltimore: Johns Hopkins University Press, p. 146.

Sigmund Freud (1905). Three Essays on the Theory of Sexuality. Standard Edition VII. London: The Hogarth Press, p. 222.

Gaston Bachelard (1942). L'eau et les rêves. Paris: José Corti, p. 157.

John Berger (1986). The Sense of Sight. New York: Pantheon, p. 240.

Robert Graves (1983). The White Goddess. An Historical Grammer of Poetic Myth. New York: Farrar, Straus and Giroux, p. 446.

Kathy Acker (1989). 'A Few Notes on Two of My Books'. The Review of Contemporary Fiction 9.3, p. 34.

Sylvia Plath (1981) 'Lady Lazarus'. The Collected Poems. New York: Harper \& Row, p. 245.

Leonora Carrington (1988). The House of Fear. Notes from Down Below. London, Virago Press, pp. 55-6.

Virginia Woolf (1966). 'Professions for Women'. Collected Essays II. London, Chatto \& Windus, p. 288.

Anne Sexton (1979). A Self-Portrait in Letters. Ed. Linda Gray Sexton and Lois Ames. Boston: Houghton Mifflin, p. 231. 